\title{
Geosciences
}

\section{Geophysical and structural survey in copper occurrence located in the northern region of the Camaquã basin (RS)}

http://dx.doi.org/10.1590/0370-44672020740103

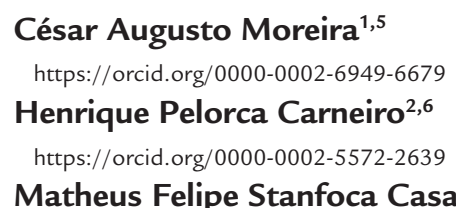

Matheus Felipe Stanfoca Casagrande ${ }^{2,7}$

https://orcid.org/0000-0003-2203-1652

Marcos Eduardo Hartwig ${ }^{3,8}$

http://orcid.org/0000-0002-2661-7506

Marco Antonio Fontoura Hansen ${ }^{4,9}$

https://orcid.org/0000-0003-2578-7973

${ }^{1}$ Universidade Estadual Paulista - Unesp, Campus de Rio Claro, Departamento de Geologia, Instituto de Geociências e Ciências Exatas,

Rio Claro - São Paulo - Brasil.

${ }^{2}$ Universidade Estadual Paulista - UNESP, Campus de Rio Claro, Programa de Pós-graduação em Geociências e Meio Ambiente,

Rio Claro - São Paulo - Brasil.

${ }^{3}$ Universidade Federal do Espírito Santo - UFES, Departamento de Geologia, Centro de Ciências Naturais e da Saúde, Alegre - Espírito Santo - Brasil.

${ }^{4} 1$ Universidade Federal do Pampa - UNIPAMPA, Campus Caçapava do Sul, Caçapava do Sul - Rio Grande do Sul - Brasil.

E-mails: ${ }^{5}$ cesar.a.moreira@unesp.br,

6hcarneiro00@gmail.com,

${ }^{7}$ mfs-casagrande@hotmail.com,

${ }^{8}$ marcos.hartwig@ufes.br,

${ }^{9}$ marcohansen@unipampa.edu.br

\begin{abstract}
The geophysical diagnosis of mineral deposits can be extremely useful in detailing mineralized zones and is a strategy for direct sampling by probing holes for content analysis. This study involves the combined use of Electrical geophysical methods (DC resistivity and Induced Polarization), geological recognition and structural field analysis, with a study of the mineralized occurrence of copper, previously described in a systematic geochemical survey carried out by the Geological Survey of Brazil (CPRM), located in the north of the Camaquã Basin, extreme south of Brazil. The mineral occurrence is partially outcropped and consists of quartz vein shafts with malachite and relic structures of sulfides, contained in schist. Structural data obtained in the field revealed the existence of a system of fracture pairs in the directions N40-50W and N70-80E. Such information is presented in the programming of the geophysical data acquisition scheme, which consisted of 6 lines of electrical tomography with $410 \mathrm{~m}$ each, in azimuthal disposition and Schlumberger arrangement, where all lines cross a single center and are separated according to an angle of $30^{\circ}$, in an attempt to cover fractures in various orientations. The $2 \mathrm{D}$ results reveal the existence of high chargeability zones $(>40 \mathrm{mV} / \mathrm{V})$ positioned below the $40 \mathrm{~m}$ depth. These data were interpolated in $3 \mathrm{D}$ visualization models and generated resistivity and chargeability maps for several depths, which integrated with previous structural data, and indicate the existence of zones with potential sulfide concentration with strong structural control, in addition to clear target recognition for direct and objective probing evaluation, with rationalization of costs.
\end{abstract}

Keywords: mineral exploration, DC resistivity, induced polarization, sulfide, 3D visualization model. 


\section{Introduction}

The mineral resources are increasingly assuming a strong importance for the maintenance, development and economic growth of the population. They are raw material sources that have wide applications in the market, which are of great importance in the sector of technological development. However, these mineral resources rely strictly on mineral research, responsible for the discovery of new occurrences and mineral deposits that are economically viable for the prospectus (Moon et al., 2006).

These discoveries have brought investments to the country for the mining and metallurgy of copper by encouraging this economic activity, since it is an important raw material used in various industrial sectors, especially in the electricity sector, in the transport sector and civil construction (MME, 2016). The wide use of this metal as a basic product for other productive sectors, is due to its technical characteristics, such as high electrical and thermal conductivity, excellent resistance to corrosion, high plasticity, ease of manufacture and alloying with other metals, excellent characteristics of abrasion and welding, and excellent basic conditions for electrolytic deposition (Chatterjee, 2007).

The increasing demand for mineral substances and the need to maintain the current consumption pattern require constant research for new deposits or studies to expand exploration reserves. The great challenge is the discovery of new exploratory frontiers or research in regions where metallogenetic conditions are favorable, but with no evidence of surface mineralization. In these cases, where potential deposits are deep, unbound from the surface or even in a geological context of high structural complexity, the use of geophysics is a highly recommended alternative for diagnosis and individualization of promising targets (Moon et al., 2006; Dentith \& Mudge, 2014).

The procedures traditionally used in the discovery and characterization of new mineral occurrences include the sampling of soil, rock and chemical analyses and direct tools like surveys, besides indirect tools, such as the geophysical methods (Moon et al., 2006).

When a prospectus is defined, the exploration work progresses through a series of detailed incremental steps, where success leads to the beginning of a new phase. On the other hand, negative results can lead to discarding the prospectus, or sale, implicating a wait for new technologies. Generally, techniques for prospecting obey a sequence of working phases that are essential for the development of the prospectus, such as generation of targets, targets for drilling, assessment of drilling resources and feasibility studies (Marjoribanks, 2010).

One of the techniques used for the search and investigation of an ore body is geophysical exploitation (Reedman, 1979). In the early stages of research, aerial geophysical methods are normally applied, aiming to define new targets at a regional scale, and subsequently terrestrial geophysical surveys with the purpose of detailing and delimiting the reserves in the subsurface (Dentith \& Mudge, 2014).

The geophysical methods are a tool of high applicability in mineral research, mainly in the research of ores and sulfides (massive and/or disseminated) because from the contrast in physical properties between a potentially mineralized target package and the overburden rock, it is possible to detect economically significant mineral accumulations (Dentith \& Mudge, 2014).

This article presents the results obtained through the geophysical methods of DC Resistivity and Induced Polarization in the Vitor Teixeira copper occurrence. The making of $2 \mathrm{D}$ models and $3 \mathrm{D}$ visualizations models entail the evaluation and determination of the geometry, the lateral continuity and depth of the mineralized body.

\section{Area of studies}

The area of studies is located in the northwestern portion of the municipality of Caçapava do Sul, located in central south of the Rio Grande do Sul State, southern Brazil (Fig. 1)

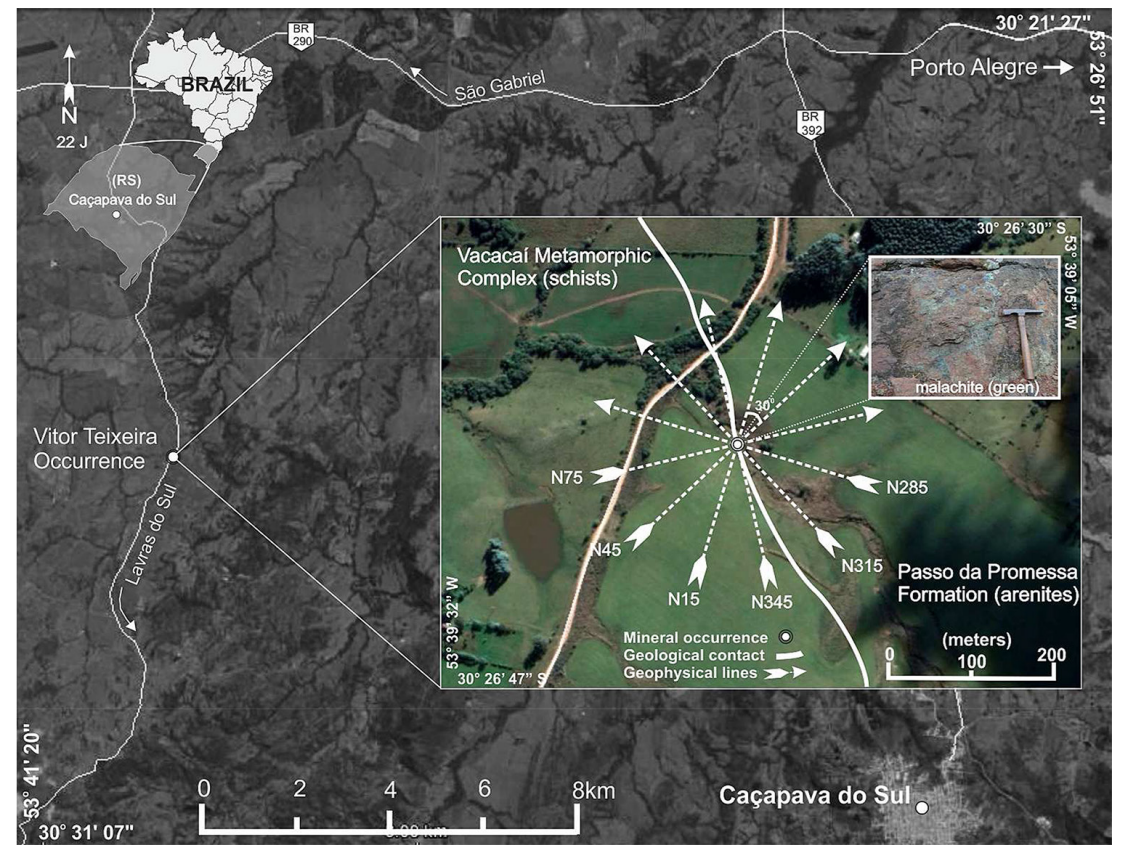

Figure 1 - Location of study area, with position of mineral occurrence, geophysical survey lines and geological contact (Adapted of Google Earth). 
The location of the studies consists of a copper mineral occurrence named Vitor Teixeira discovered in 1940 by geologists from the National Department of Mineral Production (DNPM) by geological reconnaissance (Bocchi, 1970). The mining activities in the Rio Grande do Sul State are classic. In addition to the potential and existing mineralization on the Sul-Riograndense Shield, the region of current Camaquã mines, located southeast of the Caçapava do Sul municipality, has also been the target of many foreign investments. The identification of oxidized copper minerals by British miners meant that the interest in this region was awakened in the second half of the 19th Century (Laux et al., 2000).

Occurrences of gold and silver along with copper caught the attention of governmental authorities, who started investing in this economic activity, after surveys confirmed the quality and quantity of certain reservations, through the creation of the Brazilian Company of Copper (CBC) on 02 September 1942 (Harres, 2000). Before the creation of the $\mathrm{CBC}$, three companies had explored the mine at the turn of the 19th century, but were ephemeral projects, implemented with private resources. With the domination of the state enterprise, the enterprise of mineral extraction had maintained regularity in this economic activity until the year 1996, a period that brought an end to the mining activities due to the exhaustion of deposits.

The region of study is localized at the north edge of the basin of the Camaquã, seated over igneous and metamorphic rocks of the Sul-Riograndense
Shield. This basin is a tectonic depression generated and developed during the final stages of evolution of the Dom Feliciano Belt, associated with a system of watersheds tardi and post orogenic related to final events of Brasiliana/Pan-African Orogeny (Chemale, 2000).

In the Rio Grande do Sul State, the main known mineralization of sulfides of mono or elemental metals-based nature of $\mathrm{Cu}, \mathrm{Pb}$ and $\mathrm{Zn}$, whether or not containing precious metals ( $\mathrm{Au}$ and $\mathrm{Ag}$ ), are hosted in sedimentary rocks and eruptions of the Camaquã basin, and also in plutonic rocks with chronological correlation (Silva et al., 2014).

However, great importance is assumed for the mineralization of hydrothermal - epithermal origin regarding Camaquã mines, comprising two mineralizations at the Uruguay and São Luiz mines (Laux et al. 2000). The ore occurs as veins with a prevailing to N320/70 and N70/70 respectively, cutting sandstones and conglomerates, with sulfides in a massive scale or as irregular masses inside the gangue and disseminated in sandstones and conglomerates. Chalcopyrite, bornite and chalcosite are the main minerals, and among the supergenics there occurs malachite, chrysocolla, azurite and cuprite (Laux et al. 2000).

Other significant mineralizations also occur in rocks belonging to the Vacacaí Metamorphic Complex (Bossoroca Mine). According to CPRM (1995), the seam of mineralized quartz with Au has about $350 \mathrm{~m}$ of extension, of N45/30 and is seated in a subconcordant way in metavulcanoclastics of the Campestre Formation. The Au fills microfractures in native state or is included in pyrite, accompanied by sphalerite, galena and arsenopyrite, probably related to the epigenetic hydrothermal process.

The Vitor Teixeira malachite occurrence is hosted mainly in fractures and microfractures of chlorite quartz sericite schists and/or sericite chlorite quartz schists belonging to the Vacacaí Metamorphic Complex, located in contact with the rocks of the Passo da Promessa Formation (NE portion of the geophysical surveying area), in relation to the Vacacaí Metamorphic Complex (SW portion of the geophysical surveying area).

The schists are characterized by intense fracturing, presenting several families of fractures. They have foliation predominantly N340/30, parallel to the compositional-banding. They feature gray to gray-green color, composed practically by chlorite, sericite, plagioclase and quartz as the main mineralogical assembly, epidote, apatite, kaolinite and malachite as secondary minerals (Fig. 2). Rutile and opaque, including oxide/hydroxide of iron, are part of the framework as traces. They feature a thin to very thin granulometry, sometimes aphanitic, and seamless foliation, given mainly by micaceous minerals (chlorite + sericite), quartz crystals and plagioclase deformed and oriented. Mainly around the mineral occurrence, it is common to encounter blocks of quartz in this lithotype that are scattered on the surface and decimeter veins, full of cavities, in addition to the presence of oxide and hydroxide of iron (Fig 2).

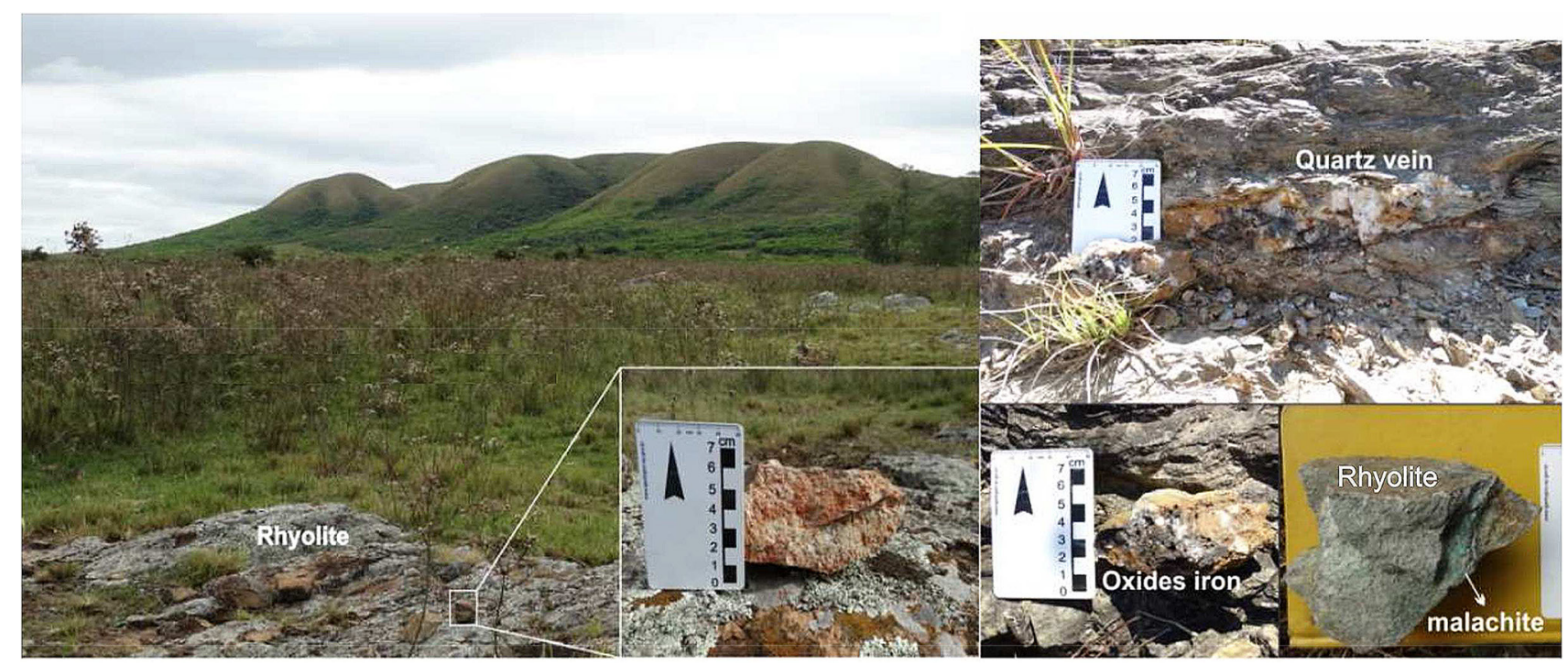

Figure 2 - Main lithology inserted in the study area, with an emphasis on veins of milky quartz, veins with iron oxides and malachite, described in geological reconnaissance. 
Locally the Passo da Promessa Formation is represented basically by medium to coarse sandstones with channeled cross stratification, having rubbles and pebbles scattered in the front planes of laminates. The conglomerates are subordinated and have a framework of well-rounded rubbles and pebbles. It is located at the base

\section{Materials and methods}

The step of acquiring data comprised a geophysical survey by land through the methods of DC Resistivity and Induced Polarization in the time domain. These have great applicability in mineral exploration of massive and/or disseminated sulfide bodies, and are independent methods, but present results of greater efficiency and safety when interpreted in conjunction (Cortês et al., 2019; Moreira et al., 2019a; Moreira et al., 2019b; Lenhare \& Moreira, 2020).

Given the indications of structural control of the eventual mineralization in subsurface, the place where indicator elements (Fig. 2) were recognized was defined as the center of the arrangement that for the acquisition of geophysical data. In this way, the electrical resistivity and chargeability measurements were obtained by means of six lines of the electric tomography oriented in azimuthal direction with angular distance of $30^{\circ}$. The lines of acquisition were oriented from the center of the arrangement, to the south and to the north, following the value of their respective azimuths (N15, N45, N75, N285, N315 and N345). This arrangement of lines in the field aimed to

\section{Results and discussions}

The step of acquiring data comprised a geophysical survey by land through the methods of DC Resistivity and Induced Polarization in the time domain. These have great applicability in mineral exploration of massive and/or disseminated sulfide bodies, and are independent methods, but present results of greater efficiency and safety when interpreted in conjunction (Cortês et al., 2019; Moreira et al., 2019a; Moreira et al., 2019b; Lenhare \& Moreira, 2020).

Given the indications of structural control of the eventual mineralization in subsurface, the place where indicator elements (Fig. 2) were recognized was defined as the center of the arrangement that for the acquisition of geophysical data. In this way, of the stratigraphic succession of the Camaquã basin, characterized by the basal contact in disconformity with the rocks of Vacacaí Metamorphic Complex (CPRM, 1995).

The set of copper carbonates and iron oxides described in the mineral occurrence under study is frequently present in peripheral portions of proven

cover several fracture directions, whose orthogonal crossing allows contrasts of physical properties related to the existence of possible accumulations of sulfides. Each line has $400 \mathrm{~m}$ of length, acquired through the technique of electrical tomography in Schlumberger arrangement, with $10 \mathrm{~m}$ spacing between non-polarizable electrodes based on copper sulfate $\left(\mathrm{CuSO}_{4}\right)$, a total of $2400 \mathrm{~m}$ for data acquisition.

We used the Terrameter LS resistivity meter, manufactured by ABEM Instrument (Sweden) which allows the realization of individual tests of Spontaneous Potential (SP), DC Resistivity (ER) and Induced Polarization (IP). After preliminary testing, this equipment was calibrated with the following parameters: transmission of $1 \mathrm{~A}$ for $1.5 \mathrm{~s}$ in each measure; two intervals of lectures with $100 \mathrm{~ms}$; and delay time of $0.5 \mathrm{~s}$. Details about the procedures for data acquisition and processing described in detail in Carneiro (2016).

These data were processed in the RES2DINV program, which automatically determines a 2D model of resistivity and chargeability of the subsurface, from data obtained through surveys of sulfide deposits with subsequent surveys in the study region (CPRM, 1995; Silva et al., 2014), and serve as prospective guides in studies of mineral exploration for hydrothermal deposits in several world cases (Allis, 1990; Irvine \& Smith, 1990; Moon et al., 2006; Salem et al., 2013; Darabi-Golestan et al., 2013; Dentith \& Mudge, 2014).

electrical imaging (GEOTOMO SOFTWARE, 2003). This program allows 2D inversion models for DC Resistivity and Induced Polarization quickly, using the algorithm of smoothness constrained least-square method.

The numeric product of two-dimensional inversion of data for each section was assembled in a single spreadsheet, which unites the position of readings along the lines (variable " $x ")$, spacing between lines (variable "y"), depth modeled by inversion (variable "z") and the value of electrical resistivity $(\mathrm{R})$ and chargeability $(\mathrm{M})$ (variable "R" or "M") that was subsequently, used for generating the $3 \mathrm{D}$ visualization models. This process was developed on the Oasis Montaj platform, where the 2D data obtained in the Res2Dinv program were interpolated to generate $2 \mathrm{D}$ visualization models by means of the method of minimum curvature, in addition to the adjustment of surface of isovalues. This procedure is described in several studies of combined use of Geoelectric methods (Moreira and Ilha, 2011; Helene et al., 2016; Camarero and Moreira 2017; Casagrande et al., 2018, Cavallari et al., 2018). the electrical resistivity and chargeability measurements were obtained by means of six lines of the electric tomography oriented in azimuthal direction with angular distance of $30^{\circ}$. The lines of acquisition were oriented from the center of the arrangement, to the south and to the north, following the value of their respective azimuths (N15, N45, N75, N285, N315 and N345). This arrangement of lines in the field aimed to cover several fracture directions, whose orthogonal crossing allows contrasts of physical properties related to the existence of possible accumulations of sulfides. Each line has $400 \mathrm{~m}$ of length, acquired through the technique of electrical tomography in Schlumberger arrangement, with $10 \mathrm{~m}$ spacing between non-polarizable electrodes based on copper sulfate $\left(\mathrm{CuSO}_{4}\right)$, a total of $2400 \mathrm{~m}$ for data acquisition.

We used the Terrameter LS resistivity meter, manufactured by ABEM Instrument (Sweden) which allows the realization of individual tests of Spontaneous Potential (SP), DC Resistivity (ER) and Induced Polarization (IP). After preliminary testing, this equipment was calibrated with the following parameters: transmission of $1 \mathrm{~A}$ for $1.5 \mathrm{~s}$ in each measure; two intervals of lectures with $100 \mathrm{~ms}$; and delay time of $0.5 \mathrm{~s}$. Details about the procedures for data acquisition and processing described in detail in Carneiro (2016).

These data were processed in the 
RES2DINV program, which automatically determines a 2D model of resistivity and chargeability of the subsurface, from data obtained through surveys of electrical imaging (GEOTOMO SOFTWARE, 2003). This program allows 2D inversion models for DC Resistivity and Induced Polarization quickly, using the algorithm of smoothness constrained least-square method.

The numeric product of two-dimen- sional inversion of data for each section was assembled in a single spreadsheet, which unites the position of readings along the lines (variable "x"), spacing between lines (variable "y"), depth modeled by inversion (variable "z") and the value of electrical resistivity $(\mathrm{R})$ and chargeability $(M)$ (variable "R" or "M") that was subsequently, used for generating the 3D visualization models. This process was developed on the Oasis Montaj platform, where the 2D data obtained in the Res2Dinv program were interpolated to generate $2 \mathrm{D}$ visualization models by means of the method of minimum curvature, in addition to the adjustment of surface of isovalues. This procedure is described in several studies of combined use of Geoelectric methods (Moreira and Ilha, 2011; Helene et al., 2016; Camarero and Moreira 2017; Casagrande et al., 2018, Cavallari et al., 2018).

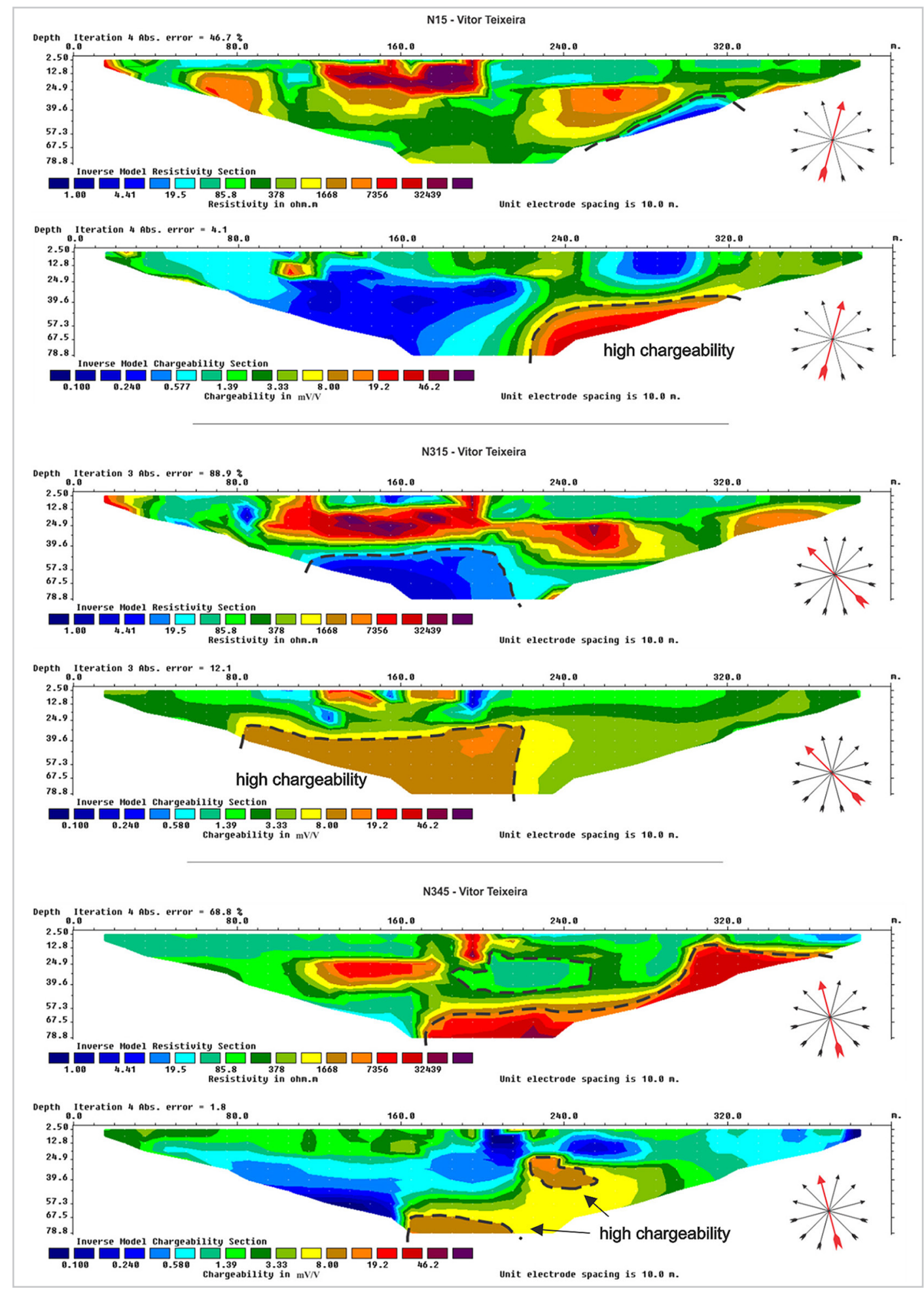

Figure 3 - Models of comparative inversion between resistivity and chargeability

presented in the form of sections $2 \mathrm{D}$, with highlight in the areas of high values (delimited in black dash). 
The comparison between the sections of line $\mathrm{N} 345^{\circ}$ reveals a quite complex pattern of coincidence between areas. However, it is important to emphasize that in the $240 \mathrm{~m}$ position, there occurs an area of moderated chargeability coincid- ing with low resistivity, highlighted by a dotted black line (Fig. 3). In the deepest regions of both inversion models, the resistive values coincide with moderate to high chargeability values, associated with sulfides scattered in cementing silica.
In large part, values of high resistivity predominate as horizontal to subhorizontal bodies with lateral extension. They are positioned primarily in shallow and deep portions, the case of the lines $\mathrm{N} 15^{\circ}, \mathrm{N} 315^{\circ}$ and $\mathrm{N} 345^{\circ}$.

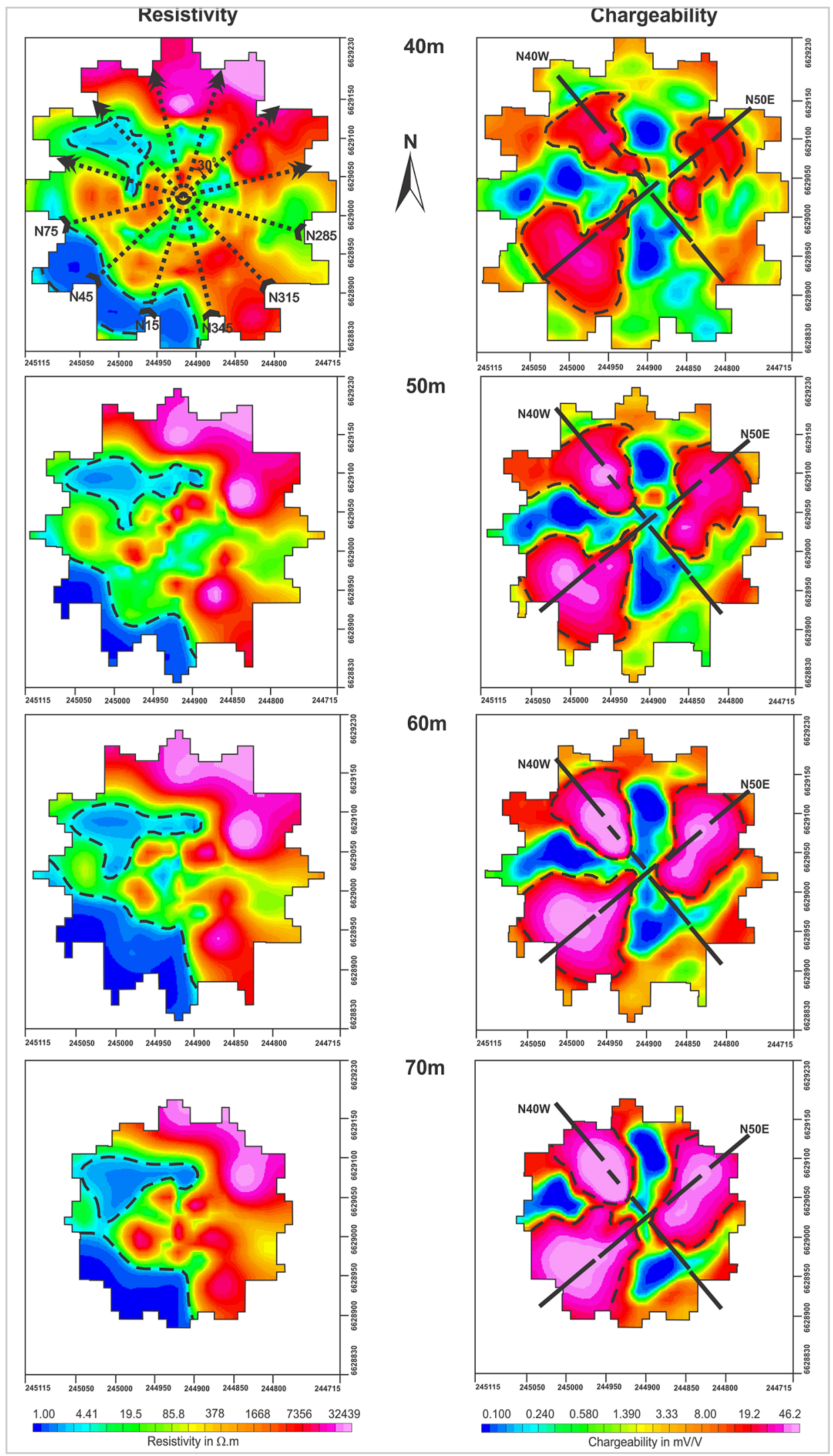

Figure 4 - Maps of resistivity and chargeability from $30 \mathrm{~m}$ to $70 \mathrm{~m}$ depth, with geophysical survey lines and principals orientation of the main regional failures. 
$3 \mathrm{D}$ visualization models were generated from 2D inversion models for each georeferenced section without topographic correction, presented in the form of maps of electrical resistivity and chargeability for various depths, as well as models of 3D isosurface (Fig. 4).

The $3 \mathrm{D}$ visualization models were made from the interpolation of $2 \mathrm{D}$ inversion products, in a total of 3090 measurements for each parameter analyzed (or and widely distributed in the volume investigated in subsurface, in a total of 6180 measurements), the sample density being much higher than that used by conventional procedures of as surveys witnessed for chemical analysis. This sample volume proportional to the elaboration of $3 \mathrm{D}$ visualization models presented in the form of multilevel maps and 3D isosurface, a procedure similar to that adopted in the modeling of deposits from chemical data for reserve estimation in mineral exploration projects (Moon et al., 2006; Dentith \& Mudge, 2014).

The product of the interpolation enabled the generation of multilevel maps, from $0 \mathrm{~m}$ to $70 \mathrm{~m}$ depth, separated from each other by $10 \mathrm{~m}$, for resistivity and chargeability variables. The measurements for the interval from $0 \mathrm{~m}$ to $30 \mathrm{~m}$ depth resulted in maps a little contradictory and homogeneous, which were disregarded in the discussions of correlation with structural measurements and metallogenesis. The other maps are presented in color scales, where the high values are represented by the hot colors and the low values by the cold colors.

The map to a depth of $30 \mathrm{~m}$ presents areas of high resistivity (around $7000 \Omega$.m) located in the center and nuclei of extreme resistive values (greater than $32400 \Omega . \mathrm{m}$ ) to the north. Exception is given to areas of low resistivity (approximately $2 \Omega . \mathrm{m}$ ), located in the southwestern portion of the map (Fig. 4). For the chargeability map corresponding to a depth of $30 \mathrm{~m}$, there is a predominance of intermediate values (around $0.5 \mathrm{mV} / \mathrm{V}$ ), with clusters of high and low chargeability located in the central region. From the $40 \mathrm{~m}$ depth, maps of resistivity and chargeability assume different configurations when compared with the maps generated at more superficial depths (Fig. 4).

The areas represented by low and high resistivity and chargeability values acquire larger dimensions, with a clear definition of areas of high values. Areas of extreme values (above $32400 \Omega . m$ ) located in the northern portion of the more superficial resistivity maps, expand to the northeastern and southeastern portions in greater depths, where they reach approximately $10000 \Omega$.m.

This pattern also applies to areas of low resistivity in northwest and southwest portions, which have approximate values of $1 \Omega . m$ on the map corresponding to $70 \mathrm{~m}$ of depth, respectively (Fig. 4).

The chargeability maps from $40 \mathrm{~m}$ depth show areas of high values, which occupy wider areas. They acquire defined geometry and rise in the chargeability values (above $46 \mathrm{mV} / \mathrm{V}$ on the map for $70 \mathrm{~m}$ ) in accordance with the increase in depth (Fig. 4).

The three areas corresponding to the highest values of chargeability appear at a depth of $40 \mathrm{~m}$ in the form of independent bodies, separated by areas of low chargeability up to $70 \mathrm{~m}$ depth (Fig. 5).
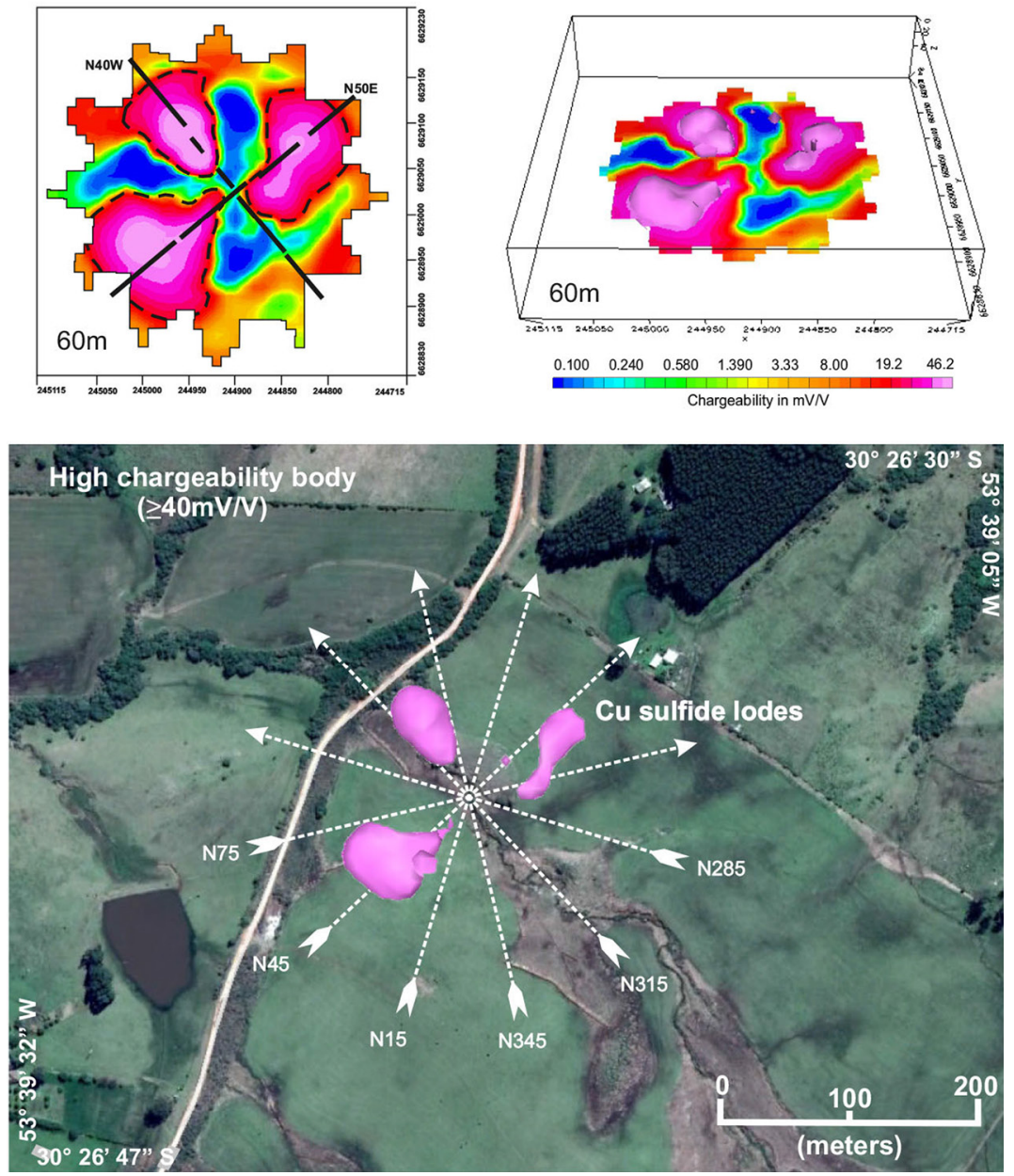

Figure 5 - 3D isosurface of the chargeability. 


\section{Conclusions}

The geological surveillance of the field allowed the characterization of mineral occurrence in the surface, represented by copper carbonate (malachite) contained in fractures of sericite chlorite quartz schists belonging to the Vacacaí Metamorphic Complex, besides impregnations of oxidized sulfides associated with quartz veins.

This step also revealed the intense fracturing in lithotypes described in the area. The structural survey was essential in programming of the geophysical survey, which adopted the azimuthal arrangement, with the placement of a central point common to all lines oriented in several directions.

The average power of the geophysical equipment $(250 \mathrm{~W})$ for cases of mineral research was compensated by the use of the Schlumberger arrangement, characterized by a high signal to noise ratio, and the programming of lines limited to $70 \mathrm{~m}$ depth, suitable for this type of equipment research objectives.

The geophysical results were processed in terms of 2D inversion models and multilevel maps, which enabled the recognition of areas of great contrast in terms of resistivity and chargeability. A review of previous studies in geophysics applied in mineral deposits revealed that similar deposits are also characterized by

\section{Acknowledgements}

The authors are thankful to National Council for Scientific and low resistivity and high chargeability.

Although the use of azimuthal arrangement in geochemical and geophysical data acquisition is questionable due to the possibility of generation of interpolation artifacts, the depth maps results clearly demonstrate a tendency for a domain of high resistivity in the NE portion and another of low resistivity in the SW portion, directly related to the existence of two distinct geological domains in the area, with geological contact recognized in the field, which also served as criterion for positioning the center of the arrangement. The NE portion is the sandstone domain area of the Passo da Promessa Formation while the SW portion represents schists of the Vacacaí Metamorphic Complex. In this sense, the results of DC resistivity reflect the geological reality described.

The analysis of the set of $2 \mathrm{D}$ inversion models and multilevel maps revealed patterns indicating the presence in sulfite mineralization. Among them are high chargeability coinciding with low resistivity (lode deposit), areas of low chargeability coinciding with areas of high resistivity (sterile areas), and moderate to high chargeability coincident with anomalies of high resistivity, (possible zones with disseminated sulfides). The analysis of multilevel maps revealed that the possible lode mineralizations are located below $40 \mathrm{~m}$.
The recognition of zones of high chargeability oriented according to the structural pattern recognized in mineralizations described elsewhere in the Camaquã Basin are strong indicators of the reflections of the geological subsurface performance of the results and the local mineral potential.

The integration of the geophysical data, indications of mineralization, structural data combined with the main regional ruptile structures, reveal the probable existence of sulfide mineral accumulations, located preferentially below $40 \mathrm{~m}$ depth structurally controlled.

The high sample density of 2D acquisitions and subsequent meeting in 3D visualization models provided contrast enhancement from a very robust statistical basis (6180 measures). The sharp contrast of physical properties is attributed to the existence of deviation (maximum and minimum) in relation to the mean of the values and the subsequent enhancement in data inversion and adoption of logarithmic scale of values.

However, regardless of the robustness of geophysical models, the effective evidence of economically viable mineral accumulations depends on drilling and sampling to define contents, a technical procedure that can be planned by indirect investigations.
Technological Development - CNPq, for the financial support whereby process number 470821/2013 (Edital Universal - 2013).

\section{References}

ALLIS, R. G. Geophysical anomalies over epithermal systems. Journal of Geochemical Exploration, v. 36, n. 1-3, p. 339-374, 1990. DOI: https://doi.org/10.1016/0375-6742(90)90060-N.

BOCCHI, P. R. Geologia da folha Caçapava do Sul, Rio Grande do Sul. Rio de Janeiro: DNPM, 1970. 76p. (Boletim 245).

CHATTERJEE, K. K. Uses of metals and metallic minerals. New Delhi: New Age International Publishers, 2007. $314 p$.

CAMARERO, P. L.; MOREIRA, C. A. Geophysical investigation of Earth dam using the electrical tomography resistivity technique. REM - International Engineering Journal, v. 70, n. 1, p. 47-52, 2017. DOI: https://doi.org/10.1590/0370-44672016700099

CAMOZZATO, E.; TONIOLO, J. A.; LAUX, J. H. Metalogênese do cinturão Dom Feliciano e fragmentos paleocontinentais associados (RS/SC). In: SILVA, M. G.; ROCHA NETO, M. B.; JOST, H.; KUYUMJIAN, R. M. (org.). Metalogênese das províncias tectônicas brasileiras. Belo Horizonte: CPRM, 2014. cap. 23, p. 517-558.

CARNEIRO, H. P. Integração de dados geofísicos e estruturais no estudo de ocorrência de cobre localizada na região norte da bacia sedimentar do Camaquã (RS). 2016. 93 f. Dissertação (Mestrado em Geociências) Instituto de Geociências e Ciências Exatas, Universidade Estadual Paulista, Rio Claro, 2016.

CASAGRANDE, M. F. S; MOREIRA, C. A.; TARGA, D. A.; ALBERTI, H. L. C. Integration of geophysical methods in the study of acid drainage in uranium mining waste. Brazilian Journal of Geophysics, v. 36, n. 4, p. 439-450, 2018. DOI: http://dx.doi.org/10.22564/rbgf.v36i4.1968

CAVALLARI, F.; MOREIRA, C. A.; HELENE, L. P. I. Environmental geophysical diagnosis of a contaminated area 
by hidrocarbons in a railway accident in the municipality of Botucatu-SP. Brazilian Journal of Geophysics, v. 36, n. 4, p. 1-14, 2018. DOI: http://dx.doi.org/10.22564/rbgf.v36i4.865

CHEMALE Jr, F. Evolução geológica do Escudo Sul-rio-grandense. In: HOLZ, M.; DE ROS, L. F. (ed.). Geologia do Rio Grande do Sul. Porto Alegre: Universidade Federal do Rio Grande do Sul / Instituto de Geociências, 2000. p.13-52.

COMPANHIA DE PESQUISA DE RECURSOS MINERAIS. Folha Passo do Salsinho, SH-22-Y-AI-4, Estado do Rio Grande do Sul. Brasília: CPRM, 1995. 372p. (Programa Levantamentos Geológicos Básicos do Brasil).

CORTÊS, A. R. P.; MOREIRA, C. A.; PAES, R. A. S.; VELOSO, D. I. K. Geophysical and metalogenetic modelling of the copper occurrence in Camaquã Sedimentary Basin, Brazilian Southern. Pure and Applied Geophysics, v. 176, p. 4955-4968, 2019. DOI: https://doi.org/10.1007/s00024-019-02190-8

DARABI-GOLESTAN, F.; GHAVAMI-RIABI, R.; KHALOKAKAIE, R.; ASADI-HARONI, H.; SEYEDRAHIMI-NYARAGH, M. Interpretation of lithogeochemical and geophysical data to identify the buried mineralized area in Cu-Au porphyry of Dalli-Northern Hill. Arabian Journal of Geosciences, v. 6, n. 11, p 4499-4509, 2013. DOI: https://doi.org/10.1007/s12517-012-0686-3

DENTITH, M.; MUDGE, S. T. Geophysics for the mineral exploration geoscientist. Cambridge: University Press, 2014. 516p.

GEOTOMO SOFTWARE. Res2Dinv (v.3.54) for 98/ME/2000/NT/XP. Geoelectrical Imaging 2D \& 3D. Penang: Geotomo Software, 2003. 125p.

HARRES, M. M. Minas do Camaquã, um estudo multidisciplinar. São Leopoldo: Editora Unisinos, 2000. 366p.

HELENE, L. P. I; MOREIRA, C. A; CARRAZZA, L. P. Applied geophysics on a soil contaminated site by chromium of a tannery in Motuca (SP, Brazil). Brazilian Journal of Geophysics, v. 34, n. 3, p. 309-317, 2016. DOI: http://dx.doi.org/10.22564/rbgf.v34i3.825

IRVINE, R. J.; SMITH, M. J. Geophysical exploration for epithermal gold deposits. Journal of Geochemical Exploration, v. 36, p. 375-412, 1990.

LAUX, J. H.; LINDENMAYER, Z. G. As Minas do Camaquã: um século de evolução de hipóteses genéticas. In: RONCHI, L. H.; LOBATO, A. O. C. (org.). Minas do Camaquã: um estudo multidisciplinar. São Leopoldo: Editora Unisinos, 2000. cap. 8, p. 133-164.

LENHARE, B. D.; MOREIRA, C. A. Geophysical prospecting over a meta-ultramafic sequence with indicators of gold mineralization in Rio Grande do Sul State, Southernmost Brazil. Pure and Applied Geophysics, v. 177, p. 5367-5383, 2020. DOI: https://doi.org/10.1007/s00024-020-02559-0

MARJORIBANKS, R. Geological methods in mineral exploration and mining. 2. ed. Heidelberger: Springer, 2010. 248 p.

MOON, C. J.; WHATELEY, M. K. G.; EVANS, A. M. Introduction of mineral exploration. 2. ed. Malden: Blackwell Publishing, 2006. 499p.

MOREIRA, C. A.; ILHA, L. M. Geophysical prospection in a copper occurrence localized in Camaquã sedimentary basin (RS). Rem: Revista Escola de Minas, v. 64, n. 3, p. 305-311, 2011. DOI: https://doi.org/10.1590/ S0370-44672011000300008

MOREIRA, C. A.; SANTOS, E. G.; ILHA, L. M.; PAES, R. Recognition of sulfides zones in Marble Mine through comparative analysis of electrical tomography arrangements. Pure and Applied Geophysics, v. 176, p. 4907-4920, 2019a. DOI: https://doi.org/10.1007/s00024-019-02243-y

MOREIRA, C. A.; PAES, R. A. S.; ILHA, L. M.; BITTENCOURT, J. C. Reassessment of copper mineral occurrence through electrical tomography and pseudo 3D modeling in Camaquã Sedimentary Basin, Southern Brazil. Pure and Applied Geophysics, v. 176, p 737-750, 2019b. DOI: https://doi.org/10.1007/s00024-018-2019-2

SALEM, S. M; SULTAN, A. A.; RAMADAN, T. M.; GAMMAL, E. Exploration of copper deposits in Wadi El Regeita area, Southern Sinai, Egypt, with contribution of remote sensing and geophysical data. Arabian Journal of Geosciences, v. 6, n. 2, p 321-335, 2013.

Received: 9 September 2020 - Accepted: 16 January 2021. 